
SYIFA
AS-SYIFA: Jurnal Pengabdian dan Pemberdayaan Kesehatan Masyarakat

\title{
Penyuluhan Personal Hygiene Untuk Faktor Risiko Penyakit Menular Pada Siswa Pesantren Sabilunnajat Ciamis Jawa Barat
}

\author{
Munaya Fauziah $^{1}$, Andriyani ${ }^{1}$, Ernyasih $^{1}$, Pawit Aryani $^{2}$ \\ ${ }^{1}$ Fakultas Kesehatan Masyarakat Universitas Muhammadiyah Jakarta \\ ${ }^{2}$ Program Studi Kesehatan Masyarakat, Fakultas Kesehatan Masyarakat Universitas Muhammadiyah \\ Jakarta \\ JL. KH. Ahmad Dahlan, Cirendeu, Ciputat, Kota Tangerang Selatan, Banten 15419 \\ Email: munaya.fauziah@umj.ac.id \\ Email: pawitaryn@gmail.com
}

\begin{abstract}
Abstrak
Personal hygiene dapat dikatakan sebagai salah satu faktor risiko terjadinya penyakit menular. Beberapa penyakit menular terjadi pada siswa pesantren seperti scabies, diare, dan Hepatitis A. Tujuan pengabdian masyarakat ini untuk melaksanakan penyuluhan personal hygiene yang menjadi faktor risiko penyakit menular pada siswa di Pondok Pesantren Sabilunnajat, Ciamis, Jawa Barat. Metode yang digunakan adalah ceramah. Penyuluhan dilaksanakan pada tanggal 23 Februari 2020. Sebelum penyuluhan dilakukan pengukuran gambaran perilaku personal hygiene siswa. Pengabdian masyarakat ini mendapatkan dukungan penuh dari pengurus yayasan dan tingkat partisipasi siswa yang sangat tinggi dan diikuti oleh seluruh siswa pesantren sebanyak 204 orang siswa. Pengumpulan informasi perilaku personal hygiene siswa pesantren menunjukkan bahwa siswa pesantren yang melaksanakan personal hygiene baik sebanyak 52,9\%, dan masih banyak siswa pesantren dengan perilaku personal hygiene yang kurang baik sebanyak 47,1\%.
\end{abstract}

Kata Kunci: personal hygiene, penyakit menular, siswa, pesantren

\begin{abstract}
Personal hygiene can be regarded as one of the risk factors for infectious diseases. Several infectious diseases occur in pesantren students such as scabies, diarrhea, and Hepatitis A. The purpose of this community service is to carry out personal hygiene counseling which is a risk factor for infectious diseases in students at the Sabilunnajat Islamic Boarding School, Ciamis, West Java. The method used is lecture. The counseling was held on February 23, 2020. Prior to the counseling, the students' personal hygiene behavior was measured. This community service received full support from the foundation's management and a very high level of student participation and was attended by all 204 Islamic boarding school students. The collection of information on personal hygiene behavior of Islamic boarding school students showed that there were $52.9 \%$ of pesantren students who carried out good personal hygiene, and there were still many pesantren students who had poor personal hygiene behavior as much as $47.1 \%$.
\end{abstract}

Key words: personal hygiene, communicable disease, students, boarding school 
ISSN (online): 2722-2055 https://jurnal.umj.ac.id/index.php/ASSYIFA
AS-SYIFA: Jurnal Pengabdian dan

Pemberdayaan Kesehatan

Masyarakat

\section{Pendahuluan}

Personal hygiene merupakan upaya yang dilakukan untuk memelihara kebersihan dan kesehatan seseorang baik kesejahteraan fisik maupun psikis, sedangkan kurang perawatan diri adalah kondisi seseorang tidak mampu melakukan perawatan kebersihan untuk dirinya sendiri (Potter \& Perry, 2005). Dalam menjalankan kehidupan sehari-hari kebersihan adalah hal yang sangat penting serta harus diperhatikan dikarenakan pada dasarnya kebersihan akan mempengaruhi kesehatan dan psikis seseorang. Nilai individu dan kebiasaan yang sering dilakukan seseorang akan mempengaruhi kebersihan bagi dirinya sendiri. Anggapan seseorang mengenai kebersihan akan mempengaruhi kesehatannya, misalnya disaat seorang sakit biasanya itu terjadi dikarenakan dia tidak menjaga kebersihan dan menganggap kebersihan adalah masalah kecil.

Pemeliharaan personal hygiene diperlukan baik bagi kenyamanan individu, keamanan, dan kesehatannya. Pada individu yang sehat akan mampu memenuhi kebutuhan kesehatannya, sedangkan individu yang sakit memerlukan bantuan perawat ataupun orang lain untuk melakukan praktik kesehatan yang rutin (Perry \& Potter, 2005).

Islam juga telah menekannkan mengenai pentingnya personal hygiene seperti yang tertera dalam QS. Al-Baqarah ayat 222 sebagai berikut :

"Sesungguhnya Allah menyukai orang-orang yang bertaubat dan menyukai orang-orang yang mensucikan diri."

Dampak dari personal hygiene terdiri dari dampak psikologis dan dampak fisik, dimana dampak fisik yaitu adanya gangguan kesehatan yang diderita seseorang karena tidak terpeliharanya kebersihan diri dengan baik (Ambarawati \& Sunarsih, 2011).

Penyakit menular adalah penyakit yang dapat ditularkan dari individu ke individu lain baik secara langsung maupun melalui tidak langsung (perantara) (Natoadmodjo, 2003). Berbagai agen penyakit yang menular bisa melalui berupa air yaitu meliputi virus, bakteri, protozoa, maupun vector yang menjadikan lingkungan air sebagai tempat tinggalnya. Menurut cara penyebarannya Water Washed Disease, Water Borne Disease, Water Related Vectors (Priyanto, 2019).

Tidak terpeliharanya sanitasi serta kebersihan diri dan lingkungan akan berkaitan dengan beberapa penularan penyakit infeksi seperti diare, kolera, typhoid, dan paratyphoid fever, disentri, penyakit cacing tambang, ascariasis, Hepatitis A dan E, penyakit kulit, trakhoma, 
AS-SYIFA: Jurnal Pengabdian dan

Pemberdayaan Kesehatan Masyarakat

schistosomiasis, cryptosporidiosis, malnutrisi, dan penyakit yang berhubungan dengan malnutrisi. Prevalensi kasus kesakitan pertahun di Indonesia akibat sanitasi buruk adalah penyakit diare sebesar $72 \%$, kecacingan $0,85 \%$, scabies $23 \%$, trakhoma $0,14 \%$, Hepatitis A 0,57\%, Hepatitis E 0,02\% dan malnutrisi 2,5\%, sedangkan kasus kematian akibat sanitasi buruk adalah diare sebesar 46\%, kecacingan $0,1 \%$, scabies $1,1 \%$, Hepatitis A 1,4\% dan Hepatitis E 0,04\% (Kemenkes, 2014).

Pondok pesantren merupakan tempat tinggal bagi ribuan santri dalam satu lokasi, dan dimana para santri akan saling berinteraksi satu dengan yang lain. Jika seorang santri terkena penyakit seperti batuk dan scabies akan dapat menular melalui udara, bersentuhan langsung ataupun melalui air. Perilaku sehat santri terkait dengan kondisi lingkungan, fasilitas, sarana prasarana dan kultur yang ada di pondok pesantren sangat menentukan kondisi kesehatan santri terhadap penyakit. Maka dari itu dilakukan pengabdian masyarakat agar siswa pesantren dapat membudayakan kebersihan diri agar hidup sehat dan produktif selama menuntut ilmu.

\section{Metode}

Penyuluhan dilaksanakan pada tanggal 23 Februari 2020 di Pesantren Sabilunnajat, Sukamaju, Desa Cileungsir, Kecamatan Rancah, Kabupaten Ciamis, Provinsi Jawa Barat. Penyuluhan dilakukan dengan metode ceramah pada total siswa Pesantren Sabilunnajat sebanyak 204 orang. Sebelum dilakukan penyuluhan terlebih dahulu dilakukan pengukuran gambaran perilaku personal hygiene siswa untuk mengetahui gambaran perilaku personal hygiene siswa pesantren. Kegiatan pengabdian masyarakat ini dilakukan oleh dosen dan mahasiswa Program Studi Kesehatan Masyarakat, Fakultas Kesehatan Masyarakat, Universitas Muhammadiyah Jakarta. Dosen berperan dalam mengkoordinasikan keseluruhan kegiatan pengabdian masyarakat serta penyiapan materi dan penyuluhan sedangkan mahasiswa berperan dalam kegiatan teknis pendukung.

\section{Hasil}

Pengabdian masyarakat berjalan dengan baik, siswa pesantren antusias mengikuti acara penyuluhan, selain itu juga diperoleh gambaran perilaku personal hygiene siswa pesantren. Selain mendapatkan ilmu yang bermanfaat mengenai personal hygiene untuk penyakit menular, siswa juga mendapatkan Al Qur'an yang dibagikan dalam kegiatan ini. Antusiasme terhadap 
AS-SYIFA: Jurnal Pengabdian dan Pemberdayaan Kesehatan Masyarakat

pelaksanaan acara ini juga ditunjukkan oleh para pengurus pesantren.

Hasil pengukuran personal hygiene siswa pesantren Sabilunnajat disajikan dalam informasi berikut ini.

Berdasarkan hasil analisis tabel 1 menunjukkan, distribusi frekuensi personal hygiene pada siswa Pondok Pesantren Sabilunnajat yaitu sebanyak 52,9\% berperilaku baik dan 47,1\% berperilaku kurang baik.

\section{Tabel 1}

\section{Gambaran Distribusi Personal Hygiene Santri di Pesantren Sabilunnajat Tahun 2020}

\begin{tabular}{|l|c|c|}
\hline $\begin{array}{l}\text { Personal } \\
\text { Hygiene }\end{array}$ & $\begin{array}{c}\text { Frekuensi } \\
\text { (n) }\end{array}$ & $\begin{array}{c}\text { Persentase } \\
(\%)\end{array}$ \\
\hline Baik & 108 & 52,9 \\
\hline Kurang & 96 & 47,1 \\
\hline Total & 204 & 100,0 \\
\hline
\end{tabular}

Berdasarkan hasil analisis univariat tabel 2 menunjukkan, dari 204 siswa yang mengikuti kegiatan pengabdian masyarakat, sebagian besar memilih jawaban sering untuk kebersihan tangan, yaitu cuci tangan dengan air mengalir dan sabun sebanyak 38,7\% cuci tangan sebelum makan sebanyak 36,8\% cuci tangan sesudah buang air kecil (BAK) sebanyak 27,0\% cuci tangan sesudah buang air besar (BAB) 36,8\% cuci tangan sebelum menyiapkan makanan sebanyak $38,7 \%$ dan cuci tangan sesudah membuang sampah sebanyak $36,8 \%$

Tabel 2.

Gambaran Distribusi Frekuensi Kebersihan Tangan Santri di Pesantren Sabilunnajat Tahun 2020

\begin{tabular}{|l|c|c|c|c|c|c|c|c|c|c|}
\hline $\begin{array}{l}\text { Perilaku } \\
\text { Kebersihan Tangan }\end{array}$ & \multicolumn{2}{|c|}{ Selalu } & \multicolumn{2}{|c|}{ Sering } & \multicolumn{2}{|c|}{$\begin{array}{c}\text { Kadang- } \\
\text { kadang }\end{array}$} & \multicolumn{2}{c|}{$\begin{array}{c}\text { Hampir } \\
\text { tidak } \\
\text { pernah }\end{array}$} & \multicolumn{2}{|c|}{$\begin{array}{c}\text { Tidak } \\
\text { pernah }\end{array}$} \\
\cline { 2 - 12 } & n & $\%$ & n & $\%$ & n & $\%$ & n & $\%$ & n & $\%$ \\
\hline $\begin{array}{l}\text { Cuci tangan dengan } \\
\text { air mengalir dan } \\
\text { sabun }\end{array}$ & 68 & 33,3 & 79 & $\begin{array}{c}38, \\
7\end{array}$ & 28 & 13,7 & 25 & 12,3 & 2 & 2,0 \\
\hline $\begin{array}{l}\text { Cuci tangan sebelum } \\
\text { makan }\end{array}$ & 47 & 23,0 & 75 & $\begin{array}{c}36, \\
8\end{array}$ & 42 & 20,6 & 37 & 18,1 & 3 & 1,5 \\
\hline
\end{tabular}


AS-SYIFA: Jurnal Pengabdian dan

Pemberdayaan Kesehatan

Masyarakat

\begin{tabular}{|l|c|c|c|c|c|c|c|c|c|c|}
\hline $\begin{array}{l}\text { Cuci tangan sesudah } \\
\text { BAK }\end{array}$ & 48 & 23,5 & 55 & $\begin{array}{c}27, \\
0\end{array}$ & 51 & 25,0 & 48 & 23,5 & 2 & 1,0 \\
\hline $\begin{array}{l}\text { Cuci tangan sesudah } \\
\text { BAB }\end{array}$ & 82 & 40,2 & 75 & $\begin{array}{c}36, \\
8\end{array}$ & 28 & 13,7 & 18 & 8,8 & 1 & 0,5 \\
\hline $\begin{array}{l}\text { Cuci tangan sebelum } \\
\text { menyiapkan makanan }\end{array}$ & 36 & 17,6 & 79 & $\begin{array}{c}38, \\
7\end{array}$ & 49 & 24,0 & 35 & 17,2 & 5 & 2,5 \\
\hline $\begin{array}{l}\text { Cuci tangan setelah } \\
\text { membuang sampah }\end{array}$ & 75 & 36,8 & 75 & $\begin{array}{c}36, \\
8\end{array}$ & 23 & 11,3 & 28 & 13,7 & 3 & 1,5 \\
\hline
\end{tabular}

Berdasarkan hasil univariat tabel 3 menunjukkan, sebagian besar responden memilih jawaban selalu untuk perilaku menjaga kebersihan tubuh, yaitu menyikat gigi dengan alat sendiri sebanyak 81,4\% dan menggunakan handuk dengan alat sendiri 80,4\%.

\section{Tabel 3}

Kebersihan Tubuh Santri

di Pesantren Sabilunnajat Tahun 2020

\begin{tabular}{|l|c|c|c|c|c|c|c|c|c|c|}
\hline $\begin{array}{l}\text { Perilaku } \\
\text { Kebersihan } \\
\text { Tubuh }\end{array}$ & \multicolumn{2}{|c|}{ Selalu } & \multicolumn{2}{|c|}{ Sering } & \multicolumn{2}{c|}{$\begin{array}{c}\text { Kadang- } \\
\text { kadang }\end{array}$} & \multicolumn{2}{|c|}{$\begin{array}{c}\text { Hampir } \\
\text { tidak pernah }\end{array}$} & \multicolumn{2}{|c|}{$\begin{array}{c}\text { Tidak } \\
\text { pernah }\end{array}$} \\
\cline { 2 - 11 } & $\mathbf{n}$ & $\mathbf{( \% )}$ & $\mathbf{n}$ & $\mathbf{( \% )}$ & $\mathbf{n}$ & $\mathbf{( \% )}$ & $\mathbf{n}$ & $\mathbf{( \% )}$ & $\mathbf{n}$ & $\mathbf{( \% )}$ \\
\hline $\begin{array}{l}\text { Menyikat gigi } \\
\text { dengan alat } \\
\text { sendiri }\end{array}$ & 166 & 81,4 & 30 & 14,7 & 4 & 2,0 & 0 & 0 & 4 & 2,0 \\
\hline $\begin{array}{l}\text { Menggunakan } \\
\text { handuk } \\
\text { dengan alat } \\
\text { sendiri }\end{array}$ & 164 & 80,4 & 25 & 12,3 & 10 & 4,9 & 1 & 0,5 & 4 & 2,0 \\
\hline
\end{tabular}

Berdasarkan hasil analisis univariat tabel 4 menunjukkan,, sebagian besar responden memilih jawaban selalu untuk perilaku kebersihan menggunakan alat makan sendiri, yaitu menggunakan piring dengan alat sendiri sebanyak 39,7\% dan menggunakan gelas dengan alat sendiri sebanyak $26,0 \%$.

Tabel 4

Distribusi Frekuensi Kebersihan Menggunakan Alat Makan Sendiri Santri di Pesantren Sabilunnajat Tahun 2020

\begin{tabular}{|c|c|c|c|c|c|c|c|c|c|c|}
\hline \multirow{2}{*}{$\begin{array}{l}\text { Perilaku } \\
\text { Menggunakan } \\
\text { Alat Makan } \\
\text { Sendiri }\end{array}$} & \multicolumn{2}{|c|}{ Selalu } & \multicolumn{2}{|c|}{ Sering } & \multicolumn{2}{|c|}{$\begin{array}{l}\text { Kadang- } \\
\text { kadang }\end{array}$} & \multicolumn{2}{|c|}{$\begin{array}{c}\text { Hampir } \\
\text { tidak } \\
\text { pernah }\end{array}$} & \multicolumn{2}{|c|}{$\begin{array}{c}\text { Tidak } \\
\text { pernah }\end{array}$} \\
\hline & $\mathbf{n}$ & $(\%)$ & & $(\%)$ & & $(\%$ & n & $(\%)$ & $\mathrm{n}$ & $(\%)$ \\
\hline Menggunakan & 81 & 39,7 & 57 & 27,9 & 30 & 14,7 & 26 & 12,7 & 10 & 4,9 \\
\hline
\end{tabular}




\begin{tabular}{|l|l|l|l|l|l|l|l|l|l|l|}
\hline $\begin{array}{l}\text { piring dengan } \\
\text { alat sendiri }\end{array}$ & & & & & & & & & & \\
\hline $\begin{array}{l}\text { Menggunakan } \\
\text { gelas dengan } \\
\text { alat sendiri }\end{array}$ & 53 & 26,0 & 73 & 35,8 & 32 & 15,7 & 39 & 19,1 & 7 & 3,4 \\
\hline
\end{tabular}

Berdasarkan hasil analisis pada tabel 5 menunjukkan, dari 204 siswa yang dijadikan sampel penelitian, sebagian besar responden memilih jawaban selalu untuk kebersihan asupan air minum, aitu 58,8\% meminum air rebusan/gallon.

Tabel 5

Gambaran Distribusi Kebersihan Asupan Air Minum Santri di Pesantren Sabilunnajat Tahun 2020

\begin{tabular}{|c|c|c|c|c|c|c|c|c|c|c|}
\hline $\begin{array}{c}\text { Perilaku } \\
\text { Asupan } \\
\begin{array}{c}\text { Air } \\
\text { Minum }\end{array}\end{array}$ & \multicolumn{2}{|c|}{ Selalu } & \multicolumn{2}{|c|}{ Sering } & \multicolumn{2}{c|}{$\begin{array}{c}\text { Kadang- } \\
\text { kadang }\end{array}$} & \multicolumn{2}{c|}{$\begin{array}{c}\text { Hampir tidak } \\
\text { pernah }\end{array}$} & \multicolumn{2}{c|}{ Tidak pernah } \\
\cline { 2 - 11 } & $\mathbf{n}$ & $(\%)$ & $\mathbf{n}$ & $\mathbf{( \% )}$ & $\mathbf{n}$ & $\mathbf{( \% )}$ & $\mathbf{n}$ & $\mathbf{( \% )}$ & $\mathbf{n}$ & $(\boldsymbol{\%})$ \\
\hline $\begin{array}{l}\text { Minum air } \\
\text { yang di } \\
\text { rebus/galon }\end{array}$ & 120 & 58,8 & 65 & 31,9 & 7 & 3,4 & 9 & 4,4 & 3 & 1,5 \\
\hline
\end{tabular}

\section{Pembahasan}

Berdasarkan hasil univariat gambaran distribusi frekuensi kebersihan tangan sebagian santri sudah perilaku baik dalam kebersihan tangan. Menurut sari (2018) penduduk yang tidak berperilaku CTPS akan berisiko 1,7 kali menderita penyakit hepatitis dibandingkan dengan mereka yang sudah berperilaku cuci tangan menggunakan sabun. Menurut Ropiah, dkk (2016) melaporkan bahwa orang dengan tidak mencuci tangan setelah BAB 2,7 kali mengalami kejadian Hepatitis A, demikian juga dengan orang yang tidak mencuci tangan sebelum makan 5,3 kali mengalami kejadian penyakit Hepatitis A. Penelitian case control di daerah wabah Hepatitis A pada kelompok umur 15-55 tahun penduduk. Didapatkan bahwa ada hubungan yang signifikan $(\mathrm{P}=0,000)$ antara mencuci tangan sebelum menangani makanan dengan terjadinya Hepatitis akut, OR=3,442 (95\% CI: 1,638-7.235)(Firdous 2005).

Menurut Parman,dkk (2017) didapatkan nilai OR=3,473 (OR >1) dengan 95\% CI 1,6697,225 menunjukkan bahwa responden yang memiliki kebersihan tangan dan kuku kurang baik berisiko 3,473 kali lebih besar menderita skabies jika dibandingkan dengan responden yang memiliki kebersihan tangan dan kuku baik.

Menurut hasil penelitian yang dilakukan oleh Hilda Iriyanti (2018) menyatakan ada 
AS-SYIFA: Jurnal Pengabdian dan

Pemberdayaan Kesehatan

hubungan yang bermakna mencuci tangan pakai sabun dengan kejadian diare dengan hasil Pvalue $=0.001$ wilayah puskesmas martapura barat. Menurut Dahlan (2013) kebiasaan mencuci tangan sesudah BAB dengan kejadian tifus memiliki OR sebesar 0,493 dengan 95\% CI=0,2880,843 dan P-value 0,013 artinya ada hubungan yang bermakna kebiasaan mencuci tangan sesudah BAB dengan kejadian tifus. Ada hubungan yang bermakna antara kebiasaan mencuci tangan pakai sabun terhadap kejadian tifus di wilayah kerja puskesmas Lambur Kabupaten Tanjung Jabung Timur Tahun 2013 dengan P-value 0,000 > 0,05.

Menurut Sahani (2020) terdapatnya hubungan kebiasaan cuci tangan dengan kejadian infeksi kecacingan dengan nilai Sig. $=0,012$, P-value $=0.02$ dan $\mathrm{P}$-value $=0.04, \mathrm{P}$-value $=0,018$, $\mathrm{P}$-value $=0,001, \mathrm{P}$-value $=0,001$, dan $\mathrm{P}$-value $=0,00$. Adapun yang dinyatakan memiliki hubungan bermakna dengan kejadian kecacingan ialah kebiasaan cuci tangan pakai sabun sebelum makan, kebiasaan cuci tangan pakai sabun sesudah BAB, kebiasaan cuci tangan pakai sabun sesudah bermain.

Pentingnya menjaga kebersihan hal itu sesuai yang dikatakan Ropiah,dkk (2016) bahwa mencuci tangan dengan sabun merupakan salah satu upaya pencegahan penyakit. Mencuci tangan dengan sabun dan air mengalir merupakan tindakan sanitasi yaitu dengan membersihkan tangan dan jari jemari menggunakan air mengalir dan sabun agar dapat memutuskan mata rantai kuman dan tangan menjadi bersih. Tangan akan menjadi agen yang membawa kuman dan menyebabkan patogen berpindah dari satu orang ke orang yang lain, baik dengan kontak langsung ataupun kontak tidak langsung (menggunakan permukaan-permukaan lain seperti handuk, gelas).

Gambaran distribusi frekuensi kebersihan tubuh menggunakan sikat gigi dan handuk milik sendiri sebagian besar santri sudah berperilaku baik. Menurut Cahyono,dkk (2010) air liur dapat menularkan Hepatitis A dalam konsentrasi yang rendah. Sehingga penggunaan sikat gigi milik sendiri merupakan salah satu perilaku yang dapat mencegah Hepatitis A (Dwiastuti, 2008). Menurut Parman,dkk (2017) didapatkan nilai OR = 4,316 (OR >1) dengan 95\% CI 2,045-9,108 menunjukkan bahwa responden yang memiliki kebersihan handuk kurang baik berisiko 4,316 kali lebih besar menderita skabies jika dibandingkan dengan responden yang memiliki kebersihan handuk baik. Menurut Mulyati (2020) tidak terdapatnya hubungan bermakna antara positif tinea versikolor dengan penggunaan pakaian secara bergantian dan handuk bergantian dengan nilai signifikansi $\mathrm{P}>0,05$. 
AS-SYIFA: Jurnal Pengabdian dan

Pemberdayaan Kesehatan

Berdasarkan hasil univariat gambaran distribusi frekuensi kebersihan menggunakan alat makan sendiri sudah perilaku baik dalam kebersihan menggunakan alat makan sendiri. Menurut Cahyono,dkk (2010) air liur dapat menularkan Hepatitis A dalam konsentrasi yang rendah. Sehingga penggunaan alat makan menggunakan alat makan sendiri merupakan salah satu pencegahan dalam penularan Hepatitis A. Hal ini sejalan dengan penelitian Rahma (2014) bahwa tukar menukar alat makan dengan P-value 0,00 dengan OR 2,09.

Gambaran distribusi frekuensi kebersihan asupan air minum dengan air yang direbus/galon sebagian besar santri sudah berperilaku baik. Menurut Sari (2018) penduduk yang melakukan pengelolaan air minum yang tidak aman akan berisiko 1,3 kali terserang penyakit hepatitis dibanding dengan mereka yang telah melakukan pengelolaan air minum dengan aman. Menurut Ropiah,dkk (2016) terdapat hubungan antara kualitas mikrobiologi air minum dengan kejadian Hepatitis A. Virus Hepatitis A dapat dimatikan dengan memasak (pemanasan $85^{\circ} \mathrm{C}$ ) sebelum dikonsumsi. Meskipun makanan dan minuman sudah dimasak terlebih dahulu, tetapi HAV masih dapat menyebar melalui makanan tersebut jika kontaminasi terjadi setelah dimasak. Menurut Cita (2013) tidak ada hubungan yang signifikan antara perilaku memasak air dengan kejadian diare dengan P-value sebesar 1,000. Hal ini berbeda dengan Febriza (2015) terdapat pengaruh yang bermakna antara sumber air yang tidak bersih dengan kejadian diare dengan Pvalue $0,002, \mathrm{OR}=0,122$ yang artinya jenis sumber air yang tidak bersih beresiko 0,122 kali terkena diare dibandingkan dengan responden yang jenis sumber airnya bersih.

Menurut Dahlan (2013) kebiasaan penggunaan air minum dengan mengkonsumsi mentah dengan kejadian tifus memiliki OR sebesar 0,447 dengan 95\% CI=0,263-0,867 dan P-value 0,020 artinya ada hubungan yang bermakna kebiasaan penggunaan air minum dengan mengkonsumsi air mentah dengan kejadian tifus.

Menurut Syahrir (2016) tidak ada hubungan antara ketersediaan air bersih dengan kejadian kecacingan dengan P-value 0,232 dikarenakan orang juga bisa terinfeksi cacingan walaupun tidak meminum air yang telah di olah atau di masak jadi apabila orang yang meminum air yang sudah di masak maka tidak akan terinfeksi kecacingan karena dengan memasak air akan terbebas dari kuman penyebab kecacingan.

Menurut Direktur Jenderal P2PL (2008) air untuk diminum harus diolah terlebih dahulu dan wadah air harus bersih dan ketutup. Air yang tidak dikelola dengan standar pengelolaan air minum rumah tangga dapat menimbulkan berbagai macam penyakit. Salah satu cara bentuk 
AS-SYIFA: Jurnal Pengabdian dan

Pemberdayaan Kesehatan

Masyarakat

pengelolaan air minum rumah tangga yang sederhana dengan dimasak. Memasak merupakan sistem untuk mematikan mikroorganisme (virus, bakteri, spora, jamur protozoa) penyebab penyakit dengan cara pemanasan (Depkes, 2008).

Gambaran distribusi personal hygiene sebagian santri memiliki perilaku personal hygiene yang baik sebanyak 52,9\%, sedangkan perilaku personal hygiene yang kurang baik sebanyak 47,1\%. Hal itu sesuai dengan Desmawati (2015) sebagian besar santri memiliki personal hygiene yang baik yaitu $61 \%$ sedangkan santri yang memiliki personal hygiene yang kurang baik sebanyak 39\%. Menurut Alvira (2014) personal hygiene yang rendah beresiko terkena Hepatitis A. Hal itu sejalan dengan penelitian Sasoka dan Satyabakti (2014) faktor risiko hygiene perseorangan terhadap kejadian Hepatitis A menunjukkan nilai $\mathrm{OR}=5,71$. Menurut Asfar (2019) terdapat hubungan personal hygiene dengan riwayat menderita diare pada siswa Sekolah Dasar Anak Indonesia (SDAI) BAZNAS Sul-Sel Kota Makassar sebanyak 25 (86,2\%) siswa yang memiliki personal hygiene kurang dengan riwayat menderita diare dengan nilai $\mathrm{P}=0,006$ dan $\alpha<0,05$. Menurut Suraya (2019) terdapat hubungan personal hygiene dengan kejadian demam tyfoid $(\mathrm{P}=0,008)$. Menurut Andini (2017) terdapat hubungan antara personal hygiene dengan kejadian kecacingan perut pada murid MI Ma'arif NU Banteran, karena nilai "p" atau $0,000<0,05$. Menurut Budiarti (2012) dilihat dari faktor presdisposisi, santri memiliki kepercayaan yang sama, dalam Islam diajarkan untuk selalu menjaga kebersihan jasmani salah satunya kebersihan diri

\section{Kesimpulan Saran}

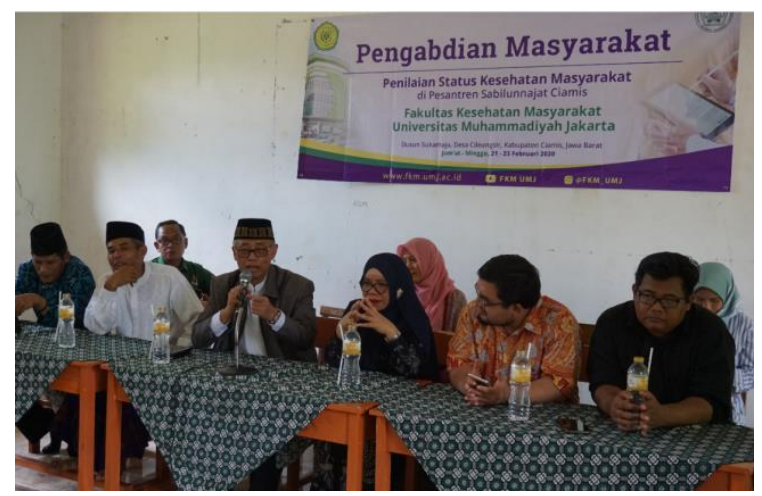

Gambar 1. Dosen dan Pengurus Yayasan Pesantren Darunnajat dalam Kegiatan Pengabdian Masyarakat Fakultas Kesehatan Masyarakat Universitas Muhammadiyah Jakarta 
AS-SYIFA: Jurnal Pengabdian dan

Pemberdayaan Kesehatan

Masyarakat

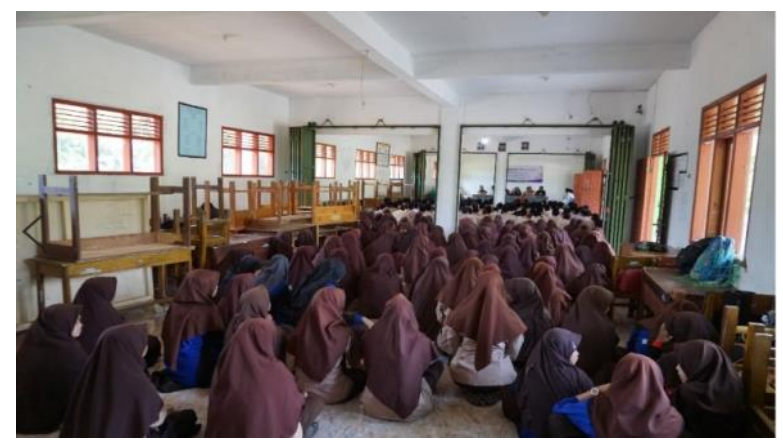

Gambar 2. Santri atau Siswa Pesantren Darunnajat mengikuti penyuluhan oleh Fakultas Kesehatan Masyarakat Universitas Muhammadiyah Jakarta

Hasil pengabdian masyarakat menunjukkan sebanyak 52,9\% siswa di Pondok Pesantren Sabilunnajat memiliki perilaku personal hygiene yang baik sedangkan perilaku personal hygiene yang kurang baik sebanyak 47,1\%. Diharapkan setelah penyuluhan pada kegiatan pengabdian masyarakat ini dapat meningkatkan adanya kesadaran dan pengetahuan siswa atau santri untuk lebih menerapkan perilaku hidup bersih dan sehat untuk mencegah penyakit terutama penyakit menular.

\section{Ucapan Terima Kasih}

Ucapan terima kasih kami sampaikan kepada Pesantren Sabilunnajat, Sukamaju, Desa Cileungsir, Kecamatan Rancah, Kabupaten Ciamis, Provinsi Jawa Barat yang telah memberikan kesempatan kepada kami untuk melakukan pengabdian masyarakat dalam upaya meningkatkan kesadaran warga agar lebih semangat menciptakan kebiasaan hidup yang sehat.

\section{Daftar Pustaka}

Alvira, L. 2014. Faktor Risiko Hepatitis A di Kecamatan Bintan Timur Kabupaten

Bintan Provinsi Kepulauan Riau. Undergraduate Thesis, Diponegoro University

Ambarwati, E.R. \& Sunarsih, T. 2011. KDPK Kebidanan : Teori dan Apilkasi. Yogyakarta: Nuha Medika

Andini N dan Utomo B. 2017. Hubungan antara Personal Hygiene dengan Kejadian Kecacingan Murid Mi Ma’arif Nu Banteran Kecamatan Sumbang Kabupaten Banyumas Tahun 2017. Keslingmas Vol. 37 No. 2 Hal. 101-239 
AS-SYIFA: Jurnal Pengabdian dan

Pemberdayaan Kesehatan

Asfar A dan Sudarman. 2019. Hubungan Personal Hygiene dengan Riwayat Menderita Diare pada Anak. Universitas Muslim Indonesia. Vol 1, No. 1, April 2019, pp 24-30 http://journal.1ldikti9.id/CPHJ/index (diakses pada 12 April 2021)

Budiarti. 2012. Tingkat Keimanan Islam dan Status Karies Gigi. Poltekkes Jakarta 1

Cahyono, SB., dkk. 2010. Vaksinasi, Cara Ampuh Cegah Penyakit Infeksi. Yogyakarta : Kanisius

Cita RS. 2013. Hubungan Sarana Sanitasi Air Bersih dan Perilaku terhadap Kejadian Diare pada

Balita Umur 10-59 Bulan di Wilayah Puskesmas Karanggan Kecamatan Setu Kota Tangerang Selatan. Universitas Islam Negeri Syarif Hidayatullah

Dahlan A, Munawar A, Supriadi. 2013. Hubungan Sanitasi Lingkungan dan Faktor Budaya dengan Kejadian Tifus di Wilayah Kerja Puskesmas Lambur Kabupaten Tanjung Jabung Timur Tahun 2013. Jurnal Ilmiah Universitas Batanghari Jambi Vol.14 No.1

Depkes RI. 2008. Pedoman Pengelolaan Promosi Kesehatan dalam Pencapaian Perilaku Hidup Bersih dan Sehat (PHBS). Jakarta: Depkes RI

Desmawati,dkk. 2015. Hubungan Personal Hygiene dan Sanitasi Lingkungan dengan Kejadian Skabies Di Pondok Pesantren Al- Kautsar Pekanbaru. JOM, Vol.2,No.1

Direktorat Jenderal Pengendalian Penyakit dan Penyehatan Lingkungan (P2PL) Departemen Kesehatan Republik Indonesia Tahun 2008 Tentang Pedoman Pelaksanaan Penyelenggaraan Hygiene Sanitasi Depot Air Minum

Dwiastuti, S. 2008. Hubungan Faktor Lingkungan dan Perilaku dengan Kejadian Hepatitis A pada Taruna Akademi Kepolisian Tahun 2008.Semarang : Tesis Kesehatan Lingkungan Universitas Dipenegoro

Febriza N, Tang UM, Maryanti E. 2015. Pengaruh Perilaku Hidup Bersih Dan Sehat (Phbs), Pendapatan dan Sanitasi terhadap Kejadian Diare di Kelurahan Meranti Pandak, Rumbai Pesisir Pekanbaru. Jurnal Ilmu Lingkungan. Universitas Riau

Firdous, U., 2005. Washing Hands Before Meal Decrease Risk of Clinical Acute. Litbang Kesehatan

H, Sari P, dkk. 2018. Hubungan Perilaku Cuci Tangan, Pengelolaan Air Minum dan Rumah Sehat dengan Kejadian Hepatitis Di Indonesia. Jurnal Ekologi Kesehatan Vol. 17 No 1, Juni $2018: 41-51$ 
AS-SYIFA: Jurnal Pengabdian dan

Pemberdayaan Kesehatan

Masyarakat

Irianty H, Hayati R, Riza Y. 2018. Hubungan Perilaku Hidup Bersih dan Sehat (PHBS) dengan Kejadian Diare pada Balita.Jurnal Kesehatan Masyarakat, Vol 8, No 1

Kemenkes RI. 2014. Kurikulum dan Modul Pelatihan Sanitasi Total Berbasis Masyarakat STBM. Jakarta: Kementerian Kesehatan RI

Mulyati, Latifah I, Utama AP. Hubungan Kebersihan Diri terhadap Kejadian Tinea Versikolor Pada Santri Di Pondok Pesantren Muthmainnatul Qulub Al-Islami Cibinong Bogor. Jurnal Ilmiah Analis Kesehatan Vol.6 No.2 ; September 2020 p-ISSN: 2088-5687 eISSN: 2745-6099

Notoatmodjo, Soekidjo. 2003 Ilmu Kesehatan Masyarakat (Prinsip-Prinsip Dasar), Cetakan Kedua. Jakarta: Rineka Cipta

Parman, dkk. 2017. Faktor Risiko Hygiene Perorangan Santri terhadap Kejadian Penyakit Kulit Skabies di Pesantren AlBaqiyatushshalihat Tanjung Jabung Barat Tahun 2017. Jurnal Ilmiah Universitas Batanghari Jambi Vol.17 No.3

Potter PA \& Perry AG. 2005. Buku Ajar Fundamental Keperawatan Konsep, Proses dan Praktik Edisi 4, Jakarta: EGC

Priyanto, D. 2019. Peran Air dalam Penyebaran Penyakit. Balaba: Jurnal Litbang Pengendalian Penyakit Bersumber Binatang Banjarnegara, 7(1), 27-28. https://doi.org/10.22435/blb.v7i1.760 (diakses pada 11 April 2021)

Rahma S dan Indriani C. 2014. Hubungan Faktor Perilaku dengan Kejadian Hepatitis A di Kecamatan Depok Kabupaten Sleman. JURNAL MKMI, Maret 2014, hal 16-20

Ropiah, dkk, N. 1122028801. 2016. Faktor Lingkungan dan Perilaku yang Berhubungan dengan Kejadian Hepatitis A Di Kecamatan Sintang Kabupaten Sintang. Universitas Muhamadyah Pontianak

Sahani W dan Limbong OS. 2020. Hubungan Kebiasaan Cuci Tangan Pakai Sabun dengan Kejadian Infeksi Kecacingan pada Anak Sekolah Dasar (Studi Literatur). Jurnal Sulolipu: Media Komunikasi Sivitas Akademika dan Masyarakat Vol. 20No.22020

Sasoka DS dan Satyabakti P. 2014. Hubungan antara Higiene Perseorangan dengan Kejadian Hepatitis A pada Pelajar atau Mahasiswa. Fakultas Kesehatan Masyarakat Universitas Airlangga 
ISSN (online): 2722-2055 https://jurnal.umj.ac.id/index.php/ASSYIFA
AS-SYIFA: Jurnal Pengabdian dan

Pemberdayaan Kesehatan Masyarakat

Suraya C dan Atikasari. 2019. Hubungan Personal Hygiene dan Sumber Air Bersih dengan Kejadian Demam Typhoid pada Anak. STIK Bina Husada Palembang. Volume 4, Nomor 3

Syahrir S dan Aswadi. 2016. Faktor yang Berhubungan dengan Kejadian Kecacingan pada Siswa SDN Inpres No. 1 Wora Kecamatan Wera Kabupaten Bima. Volume 2, No. 1 
